\title{
N-Picolyl Derivatives of Kemp's Triamine as Potential Antitumor Agents: A Preliminary Investigation
}

\author{
Celeste Aida S. Regino ${ }^{\dagger}$, Suzy V. Torti $§$, Rong Ma $§$, Glenn P.A. Yap ${ }^{\ddagger}$, Kevin A. Kreisel ${ }^{\ddagger}$, Frank \\ M. Torti $\$$, Roy P. Planalp $\ddagger$, and Martin W. Brechbiel $\dagger^{*}$ \\ $\dagger$ Radiation Oncology Branch, National Institute of Cancer, National Institutes of Health, 10 Center Drive, \\ Bethesda, MD 20892 \\ §Department of Biochemistry, Wake Forest School of Medicine, Winston-Salem, NC 27157 \\ †Department of Chemistry, University of New Hampshire, Durham, NH 03824 \\ fDepartment of Chemistry \& Biochemistry, University of Delaware, Newark, DE 19716
}

\section{Abstract}

Pre-organized tripodal ligands such as the $N$-picolyl derivatives of $c i s, c i s-1,3,5$-triaminocis,cis-1,3,5-trimethylcyclohexane (Kemp's triamine) were prepared as analogs to $N, N$ ', $N$ "'- tris (2-pyridylmethyl)-cis,cis-1,3,5-triaminocyclohexane (tachpyr) in hopes of enhancing the rate of formation and stability of the metal complexes. A tricyclic bisaminal was formed via the reduction of the Schiff base while the tri(picolyl) derivative was synthesized via reductive amination of pyridine carboxaldehyde. Their cytotoxicities to the HeLa cell line were evaluated and directly compared to tachpyr and $N, N^{\prime}, N^{\prime \prime}$ - tris(2-pyridylmethyl)-tris(2-aminoethyl)amine (trenpyr). Results indicate that $N, N^{\prime}, N^{\prime \prime}$-tris (2-pyridylmethyl)-cis,cis-1,3,5-triamino-cis,cis-1,3,5-trimethylcyclohexane (Kemp's pyr) exhibits cytotoxic activity against the HeLa cancer cell line comparable to tachpyr $\left(\mathrm{IC}_{50} \sim 8.0 \mu \mathrm{M}\right)$. Both Kemp's pyr and tachpyr show higher cytotoxic activity over the aliphatic analogue of trenpyr $\left(\mathrm{IC}_{50} \sim 14 \mu \mathrm{M}\right)$ suggesting that the major contributor to the activity is the ligand's ability to form a stable and tight complex and that the equatorial/axial equilibrium impacting the complex formation for the cyclohexane-based ligands is not significant.

\section{Introduction}

Iron is the most abundant transition metal element in the human body (34-60 mg/kg body weight) $1 ; 2$ and has involvement in acid-base reactions, oxidation-reduction catalysis, and bioenergetics. ${ }^{1}$ It is essential in all living organisms, yet at the same time highly toxic being implicated in oxidative stress through the production of free radicals such as hydroxyl radical, $3 ; 4$ apoptosis, ${ }^{5 ; 6}$ and even cancer. ${ }^{3-5 ; 7}$ To circumvent the hazardous effects of acquiring redox active iron in the environment, special transport and storage proteins have been developed by nature. Examples of these transport and storage proteins are p97, transferrin, transferrin receptors, and ferritins. $1 ; 8-10$

An increased level of expression for these iron transport proteins such as transferrin and its receptor in actively proliferating cells such as hematopoietic cells $11 ; 12$ has been shown in a number of studies. ${ }^{11-13}$ This suggests a heightened need for iron $7 ; 11 ; 13 ; 14$ presumably for use in the M2 subunit of the ribonucleotide reductase, 8 the rate-controlling enzyme in DNA

*Correspondence to: Martin W. Brechbiel, Ph.D., Radioimmune \& Inorganic Chemistry Section, Radiation Oncology Branch, NCI, NIH, 10 Center Drive, Building 10, Room B3B69, Bethesda, MD 20892-1002, Fax: (301) 402-1923, e-mail: martinwb@mail.nih.gov. 
synthesis. $11 ; 15$ As iron is essential in cell growth, deficiency and deprivation of iron in cell lines such as human lymphocytes, ${ }^{11 ; 16} \mathrm{HeLa},{ }^{17}$ and erythroblasts $18-20$ have been shown to impair DNA synthesis by inhibiting ribonucleotide reductase $1312 ; 20-22$ thus preventing cell proliferation. Depletion of iron has also been shown to exert an anti-proliferative effect in various cell lines such as neuroblastoma 23 and lymphocytes, ${ }^{11}$ to induce in cell cycle arrest at various stages, and to induce apoptosis. 11;15;24-27

A distinct feature of cancer cells that investigators have exploited in the search for effective chemotherapeutic agents is that tumor cells grow at a rate faster than most normal cells. Hann and coworkers 28 have shown that tumor cells grow better in an iron-rich environment. Consequently, iron deprivation by using metal chelators seems a logical strategy for designing new anticancer drugs to inhibit tumor growth. Effective therapies for human iron-overload diseases such as hemochromatosis, thalassemias, and sickle cell disease demonstrate that metal chelators act as iron-deprivation agents in vivo. Examples of metal chelators that have been considered for cancer therapy are desferrioxamine (DFO), ${ }^{29-33}$ pyridoxal isonicotinoyl hydrazones (PIHs) ${ }^{15 ; 34}$ and the tripodal amine $N, N$ ', $N$ "-tris(2-pyridylmethyl)-cis,cis-1,3,5triaminocyclohexane (tachpyr). 27 Tachpyr has been shown to be cytotoxic towards mouse bladder tumor cultured cells (MBT2) with an $\mathrm{IC}_{50} \sim 5 \mu \mathrm{M} .{ }^{27}$ In addition to exhibiting a significant cytotoxic effect through the induction of apoptosis, tachpyr's effects are independent of p53-activated apoptosis 35 offering an advantage over numerous chemotherapeutic drugs.

Tachpyr is based on cis,cis-1,3,5-triaminocyclohexane (tach), which can readily flip from an open all-equatorial conformation into a closed all-axial conformation to encapsulate metal ions (Figure 1). The metal complexes formed with +2 first row transition metals such as copper, zinc and iron show a regular octahedral structure with all three cyclohexane amines in the axial position. ${ }^{36 ; 37}$ Synthesis of similar tripodal-based ligands that are pre-organized may enhance the rate of formation and the stability of the metal complex ${ }^{38-40}$ formed thereby improving the iron-depleting activity. In this study, use of Kemp's triamine (cis,cis-1,3,5-triaminocis,cis-1,3,5-trimethylcyclohexane) which has the same cyclohexane base as tach, was investigated as a platform for new chelation agents. However, unlike tach, the cis amino groups are predisposed in an all-axial conformation by the presence of the three cis methyl groups analogous to Kemp's acid (Figure 1). ${ }^{41}$ The additional pre-organization was hypothesized to increase the rate of formation and stability of the metal complex because less conformational change, i.e., no transition from equatorial to axial configuration, would be required to form the metal complex. In turn, increased biological activity was anticipated. The preference for a triaxial geometry should suppress dechelation, increasing the overall complex stability. As an additional comparison to the pre-organization strategy, the cyclohexane-based ligands of tach and Kemp's are compared to the more open configuration of the tris(2-aminoethyl)amine (tren) (Figure 1) based analog wherein all three amines and the three pyridyl donors are assembled in more open and flexible aliphatic chains. Synthesis of the tri(picolyl) derivative of Kemp's triamine (Kemp's pyr) as an analogue to tachpyr and its cytotoxic activity to HeLa cell lines in comparison to both tachpyr and trenpyr are described in this paper.

\section{Results and Discussion}

\section{Synthesis}

Synthesis of Kemp's pyr began with the preparation of the Kemp's triamine base framework. The triamine was prepared from the commercially available Kemp's triacid as described in the literature. ${ }^{41}$ A modification of the reported method was employed for the synthesis of the azide intermediate wherein a saturated solution of the sodium azide was used along with a shorter reaction time to obtain yields comparable to those previously reported. For the syntheses of both tachpyr and trenpyr, ${ }^{5 ; 6 ; 42}$ the picolyl derivatives were prepared by first forming their 
corresponding imines (Schiff bases) which were subsequently reduced to the corresponding substituted amines using sodium borohydride. This approach was applied first towards the synthesis of Kemp's pyr from the respective triamine, however, the expected Schiff base imines were not isolated in the first step of the reaction. Treatment of this product mixture using sodium borohydride afforded no change in composition which indicated that reducible imine groups were not present and that neither was the major product in equilibrium with an imine. Varying the reaction ratio of the starting triamine to the pyridine-2-carboxaldehyde from a 1:3 to 1:2, and even to a 1:1 gave the same major product. Isolation by column chromatography and characterization of the major product yielded a $\mathrm{m} / \mathrm{z}$ of 350.4 suggesting this product to have only two picolyl arms; proton NMR confirmed this inequivalency as well. Proton NMR also indicated two types of methyl group with a ratio of $2: 1(6 \mathrm{H}: 3 \mathrm{H})$ and a unique $\mathrm{CH}$ group $(2 \mathrm{H})$ suggesting a plane of symmetry. NOESY experiments indicated no correlation for the methine proton to any methyl or methylene protons and only a weak one to an aromatic proton suggesting that this unique proton was directed away from all other groups. Based on the mass spectral data and 1D and 2D NMR spectroscopic analyses, the major product of this specific route is proposed to be the tricyclic bis(aminal), KP1/2 (Figure 2). The formation of KP1/2 presumably originates from the formation of a mono-imine initially, the double bond of which is then attacked by the neighboring nucleophilic amine producing an aminal. A second imine forms from the third free amine and is then nucleophilically attacked by the neighboring secondary amine forming the third fused ring (Figure 5). This proposed mechanism is probably promoted by the framework of the cyclohexane base of Kemp's triamine placing the three primary amines in close proximity. Menger and coworkers observed similar behavior with the formation of the cyclic anhydride/acid chloride in the first step of Kemp's triamine synthesis from the triacid, ${ }^{41}$ with the neighboring carboxyl groups acting as amide catalysts. 43

Due to these complications, the stepwise tris-imine hydride reduction route to synthesize Kemp's pyr that had been successful for both tachpyr and trenpyr was abandoned. Instead, reductive amination of the pyridine carboxaldehyde using cyanohydridoborate was investigated. ${ }^{44 ; 45}$ Reaction of the triamine with the aldehyde afforded a near quantitative yield (85\%) of Kemp's pyr with less than 5\% of the tricyclic amine (KP1/2) byproduct (NMR). Isolation and subsequent characterization of Kemp's pyr by mass spectra and NMR confirmed the product. As expected, the three pyridyl rings and the "benzylic" methylene protons were spectroscopically equivalent as expected for a $\mathrm{C}_{3}$-symmetric substance.

\section{Structural Analysis: $\mathrm{Cu}(\mathrm{II})$ and $\mathrm{Zn}(\mathrm{II})$}

To confirm the structure of Kemp's pyr and investigate its metal complexing properties, the $\mathrm{Cu}$ (II) and $\mathrm{Zn}$ (II) complexes were prepared. Two independent complexes (a and $\mathbf{b}$ ) were found in the asymmetric unit for the $\mathrm{Cu}$ (II) complex of Kemp's pyr (Figure 6), both consisting of a mononuclear [Cu(II)-Kemp's pyr] cation each with two $\mathrm{BF}_{4}{ }^{-}$anions and three ethanol solvents associated with it. Selected bond distances and bond angles are listed in Table 2.

Isomer $\mathbf{b}$ is a six-coordinate complex that can be described as an antitrigonal geometry (ideal $\varphi=60^{\circ}$ ) distorted towards trigonal prism (ideal $\varphi=0^{\circ}$ ). ${ }^{46}$ The three cyclohexyl amino $\mathrm{N}_{\mathrm{cy}}$ atoms and the three $\mathrm{N}_{\mathrm{py}}$ atoms form two staggered equilateral triangles $\left(\varphi=46.2^{\circ}\right)$ with the $\mathrm{Cu}$ (II) metal located between the two triangles. This isomer also shows the tetragonal distortion that is typical for a hexacoordinate $\mathrm{Cu}(\mathrm{II})$ causing a Jahn-Teller effect. In this structure, the two axial bonds (Cu2-N7 and Cu2-N12) have shorter bond lengths (2.057 $\AA$ ) than the rest of the $\mathrm{Cu}-\mathrm{N}$ bond distances $(2.18 \AA$ ) opposite of the elongated axial bonds found in the $\mathrm{Cu}$ [tachpyr] complex. 47

Isomer a, on the other hand, is a five-coordinate complex that can be described as a distorted square pyramidal geometry with one pyridyl arm unbound to the $\mathrm{Cu}(\mathrm{II})$. The average coordinated $\mathrm{Cu}-\mathrm{N}_{\mathrm{cy}}$ and $\mathrm{Cu}-\mathrm{N}_{\mathrm{py}}$ are $2.100 \AA$ and $2.039 \AA$, respectively. The third $\mathrm{Cu}-\mathrm{N}_{\mathrm{py}}$ 
distance is $2.704 \AA$ and is longer than the corresponding sum of van der Waals radii ( $2.46 \AA$ ) 48 indicating that it is not coordinated to the $\mathrm{Cu}$ (II) ion. However, unlike the $\mathrm{Cu}(\mathrm{II})$ complex of tach-6-Me-pyr wherein the third pyridine ring is entirely twisted away from the copper center due to the steric effects of three methyl groups on the pyridine rings, 47 the third pyridine group on a still faces the $\mathrm{Cu}(\mathrm{II})$ center potentially blocking access to the sixth coordination site.

Surprisingly, the average torsion angle for isomer $\mathbf{a}\left(47.8^{\circ}\right)$ is smaller than that for isomer $\mathbf{b}$ $\left(49.2^{\circ}\right)$ indicating that there is possibly more strain in the five-coordinate complex than there is on the six-coordinate. This may indicate that the six-coordinate is the favored isomer. Also, as expected, these torsional angles are smaller than those found in different complexes of tach derivatives, which typically average from $49^{\circ}$ to $53^{\circ} .{ }^{49}$ Presumably this is due to the presence of the trimethyl groups on the equatorial positions for the Kemp's based ligand. In accordance with what is observed for the tach-based ligands, we would expect that complexation of a larger ionic radius metal ion would spread the amines further apart and flatten the cyclohexyl ring. We also would expect that such a complex of a very large metal ion would concomitantly form a less stable complex with Kemp's pyr than tachpyr due to the strain in the cyclohexyl ring.

To observe the lability of the metal in aqueous solution, a solution of the complex was studied by RP-HPLC using a gradient of $100 \%$ aqueous buffer of $0.05 \mathrm{M} \mathrm{HOAc}^{-} \mathrm{NEt}_{3}(\mathrm{pH} 6.5)$ to $100 \%$ $\mathrm{MeOH}$ in 25 minutes. A single peak was observed $\left(\mathrm{R}_{t}=16.3 \mathrm{~min}\right.$ vs $\mathrm{R}_{t}=18$ min for $\mathrm{Cu}$ [tachpyr] $)$ with no visible free ligand $\left(\mathrm{R}_{\mathrm{t}}=24.95 \mathrm{~min}\right)$ under these conditions indicating that the complex stays intact.

The Zn(II) complex of Kemp's pyr was also synthesized to further confirm structural details as well as to test the ability of the Kemp's pyr to form stable metal complexes with other metals. The stability of the corresponding Zn(II) complex of Kemp's pyr was observed in both the NMR $\left(\mathrm{D}_{2} \mathrm{O}\right)$ and the RP-HPLC. However, unlike the $\mathrm{Cu}$ (II) complex of Kemp's pyr, the Zn (II) complex forms a six-coordinate complex in solution as observed from the equivalency of the pyridine rings in the proton NMR of the complex.

Cytotoxicity studies indicate that Kemp's pyr (ave. $\mathrm{IC}_{50}=8.0 \mu \mathrm{M}$ ) has comparable activity to tachpyr (ave. $\mathrm{IC}_{50}=8.8 \mu \mathrm{M}$ ), indicating that while an equilibrium may exist between the two isomers, Kemp's pyr still chelates and sequesters essential metals. Presumably, this is the cause of the cytotoxicity. ${ }^{27}$ In comparison, both these complexes are somewhat more cytotoxic than that measured for the more open, acyclic configuration of trenpyr $\left(\mathrm{IC}_{50}=13.5 \mu \mathrm{M}\right)$. This may be attributed to the differences in rate of formation for the trenpyr metal complex, since this ligand must undergo a larger entropic change than either the cyclohexane-based tachpyr or Kemp's pyr. Ultimately, small differences in their stability constants, currently being studied, may also contribute to the differences in their cytotoxicity.

As expected, the starting material, Kemp's triamine (ave. $\mathrm{IC}_{50}=658 \mu \mathrm{M}$ ), has little or no cytotoxicity as was also observed for the base tach amine. ${ }^{36}$ This is due to the inability of the ligand to form a tight complex with the metal. This is observed in the RP-HPLC of the metal complex solution wherein no peak was observed for the complex.

The tricyclic $\mathrm{KP}^{1 / 2}$ (ave. $\mathrm{IC}_{50}=834 \mu \mathrm{M}$ ) also shows little or no cytotoxicity, as it is likely limited to forming the more open four or five coordinate complex making it more labile. This is not unlike the $\mathrm{Cu}$ (II) complex with tach-6-Me-pyr, ${ }^{47}$ which is unable to sequester metal ions effectively in an in vitro cell culture milieu.

\section{Conclusions}

The geometry and conformational locking of the cyclohexane framework of Kemp's triamine increases the availability and thus nucleophilicity of the three triaxial primary amines as 
compared to the tach analogue. This favors formation of tricyclic KP1/2 over Kemp's pyr as the thermodynamic product. Though the cytotoxicity of this tricyclic ligand is not significant in this arena, this intermediate may be used in the development of other novel metal chelators, as this triamine provides a novel platform/base for design of metal chelators. Direct reductive amination provides the desired kinetic product, Kemp's pyr, with minimal production of KP1/2.

Preorganization of the pyridyl substituted amines of the tripod into the triaxial conformation appears not to increase the cytotoxicity of the ligand. Although both these ligands show higher cytotoxicity as compared to the aliphatic analogue trenpyr $\left(\mathrm{IC}_{50}=13.5 \mu \mathrm{M}\right)$, we surmise that the ability of the ligand to form a stable complex is a major contributor in the cytotoxicity of these ligands. Kemp's pyr is able to form stable complexes with both copper and zinc and may be able to form stable complexes with other metals such as iron. As there seems to be more strain in the cyclohexyl ring on complex formation, larger metal cations may be unable to form stable complexes with Kemp's pyr.

Additionally, substitution at the equatorial position, i.e., addition of the three methyl groups in Kemp's pyr, also appears not to measurably impact the cytotoxicity of tachpyr. This position may be suitable for further derivatization to create novel tachpyr/ Kemp's pyr derivatives altering lipophilicity, pharmacodynamics and pharmacokinetics, as well as furthering the design of bifunctional ligands for conjugation to potential drug delivery systems.

In terms of evaluating these potential chelating agents for the development of new chemotherapeutic drugs, tachpyr remains superior to Kemp's pyr with the overall yield for synthesis of the latter being low $(\sim 25 \%)$ as compared to tachpyr $(\sim 60 \%)$ from the respective triacid starting materials.

\section{Experimental Section}

\section{General Experimental Procedures}

Proton and ${ }^{13} \mathrm{C}$ NMR spectra were obtained by using a Gemini or a Mercury $300 \mathrm{MHz}$ spectrometer. Chemical shifts are reported in ppm on the $\delta$ scale relative to TMS or TSP for ${ }^{1} \mathrm{H}$ NMR spectra and relative to the solvent $\left(\mathrm{CDCl}_{3}\right)$ or an external standard (methanol for $\mathrm{D}_{2} \mathrm{O}$ ) for ${ }^{13} \mathrm{C}$ NMR spectra. Proton chemical shifts are annotated as follows: ppm (multiplicity, integration, coupling constant in $\mathrm{Hz}$ ). The positive-ion mode $\mathrm{FAB} / \mathrm{MS}$ spectra were obtained using a JEOL SX $102 \mathrm{GC} /$ direct probe. Time-of-flight mass spectra using an electrospray ionization mode (ESI/TOF/MS) were obtained using Waters' LCT Premier with the Waters' 1525 microliter binary HPLC pump. Elemental analyses were obtained from the Department of Chemistry University of Florida Spectroscopic Services (Gainesville, FL).

Analytical HPLC were performed using a Beckman system equipped with Model 114M pumps controlled by System Gold software and a Model 165 dual wavelength UV detector (254 and $280 \mathrm{~nm}$ ). Chromatography was performed on a Beckman Ultrasphere ODS C18 reversed phase column $(5 \mu \mathrm{m}$ particles, $4.6 \times 250 \mathrm{~mm})$ with a guard column $(8 \mu \mathrm{m}$ particles, $4.6 \times 7.5 \mathrm{~mm})$ using a binary solvent $\left(\mathrm{A}=0.05 \mathrm{M} \mathrm{Et}_{3} \mathrm{~N}-\mathrm{HOAc} \mathrm{pH} \sim 6.5, \mathrm{~B}=\mathrm{MeOH}\right)$ linear gradient $(100 \%$ $B$ over $25 \mathrm{~min}$ ) at a rate of $1.00 \mathrm{~mL} / \mathrm{min}$. A secondary system using a linear gradient of acetonitrile $(\mathrm{A}=$ water, $\mathrm{B}=\mathrm{MeCN}, 100 \% \mathrm{~B}$ over $25 \mathrm{~min}$ ) at a rate of $1.00 \mathrm{~mL} / \mathrm{min}$ was also used to confirm purity.

\section{Materials}

All solvents and reagents were obtained from Aldrich (St. Louis, MO), Mallinckrodt Chemicals (Philipsburg, NJ), Fisher Scientific (Atlanta, GA), Lancaster (Windham, NH), Fluka (Ronkonkoma, NY), or Alfa (Danvers, MA) and were used as received. 
Tachpyr and trenpyr were prepared as previously reported. ${ }^{4-6 ; 42}$ Kemp's triamine was synthesized according to the scheme developed by Menger and coworkers. 41

Aluminum Oxide Type T (Activity I) gel for column chromatography (70-230 mesh ASTM), silica gel for column chromatography (230-400 mesh ASTM), aluminum oxide Type T precoated plates for TLC, and silica gel $60 \mathrm{~F}$ pre-coated plates for TLC were obtained from EM Science (Gibbstown, NJ).

\section{Synthesis of 3,5-bis(2-pyridyl)-cis,cis-1,7,9-trimethyl-2,4,6-triazatricyclo[5.3.1.0 4,9 ] undecane (KP 1/2)}

Kemp's triamine $(\mathrm{HCl})_{3}(0.10 \mathrm{~g}, 0.32$ mmole $)$ was dissolved in a solution of $\mathrm{NaOH}(0.04 \mathrm{~g}$, $0.95 \mathrm{mmole})$ in $\mathrm{H}_{2} \mathrm{O}(1.0 \mathrm{~mL})$. Benzene $(25 \mathrm{~mL})$ was added to the aqueous solution and water was removed by refluxing the mixture using a Dean-Stark apparatus for 4 hours. The solution was then cooled to room temperature after which 2-pyridinecarboxaldehyde $(0.040 \mathrm{~mL}, 0.32$ mmole) was added. The mixture was refluxed overnight and solvent removed in vacuo to give a brown oil. The product was purified by column chromatography using a slow gradient of $\mathrm{MeOH}(1-10 \%)$ in $\mathrm{CH}_{2} \mathrm{Cl}_{2}(0.07 \mathrm{~g}, 75 \%$ yield). The $\mathrm{HCl}$ acid form was isolated by bubbling $\mathrm{HCl}$ into a solution of $\mathrm{KP} 1 / 2$ in dioxane. FAB/MS: $m / z\left[\mathrm{C}_{21} \mathrm{H}_{27} \mathrm{~N}_{5}+\mathrm{H}\right]^{+}$calcd: 350.2 , found: 350.3. ${ }^{1} \mathrm{H}$ NMR $\left(\mathrm{CDCl}_{3}\right): \delta 1.23\left(\mathrm{~s}, 3 \mathrm{H}, \mathrm{CH}_{3}\right), 1.52\left(\mathrm{~d}, 2 \mathrm{H}, \mathrm{J} 16 \mathrm{~Hz}, \mathrm{CH}_{2}\right), 1.65\left(\mathrm{~s}, 6 \mathrm{H}, \mathrm{CH}_{3}\right)$, $1.76\left(\mathrm{~d}, 2 \mathrm{H}, J 20 \mathrm{~Hz}, 11 \mathrm{CH}_{2}\right), 2.42\left(\mathrm{~d}, 2 \mathrm{H}, J 16 \mathrm{~Hz}, \mathrm{CH}_{2}\right), 3.85(\mathrm{~s}, 2 \mathrm{H}, \mathrm{CH}), 6.80(\mathrm{q}, 1 \mathrm{H}, J$ $3.5 \mathrm{~Hz}, A r), 7.15(\mathrm{dd}, 2 \mathrm{H}, J 6,1 \mathrm{~Hz}, A r), 7.28(\mathrm{t}, 1 \mathrm{H}), 7.75(\mathrm{dt}, 1 \mathrm{H}, J 8.1,2.3 \mathrm{~Hz}, A r), 8.12(\mathrm{dd}$, $1 \mathrm{H}, J$ 4.6, $2.3 \mathrm{~Hz}, A r), 8.29$ (dd, $1 \mathrm{H}, J$ 4.6, $2.3 \mathrm{~Hz}, A r), 9.24$ (d, $1 \mathrm{H}, J 8.1 \mathrm{~Hz}, A r), 10.0$ (broad, $2 \mathrm{H}, \mathrm{NH}) .{ }^{13} \mathrm{C}$ NMR with DEPT $\left(\mathrm{CDCl}_{3}\right): \delta\left(\mathrm{CH}_{3}\right) 27.2,29.8 ;\left(\mathrm{CH}_{2}\right) 42.6,47.1,47.9 ;(\mathrm{CH}) 68$, 121.0, 123.0, 124.8, 127.1, 136.0, 138.0, 148.0, 148.1; ( $\left.\mathrm{C}_{\text {quat }}\right) 51.8,53.5,159,160.3$. Analysis calculated for $\mathrm{C}_{21} \mathrm{H}_{27} \mathrm{~N}_{5} \bullet 3.75 \mathrm{HCl} \cdot \mathrm{C}_{4} \mathrm{H}_{4} \mathrm{O}_{2}$ : C, 52.56; H, 7.11; N, 10.58. Found $\left(\mathrm{C}_{21} \mathrm{H}_{27} \mathrm{~N}_{5} \cdot 3.75 \mathrm{HCl} \cdot 2 \mathrm{C}_{4} \mathrm{H}_{8} \mathrm{O}_{2}\right): \mathrm{C}, 52.65 ; \mathrm{H}, 6.69 ; \mathrm{N}, 10.76$.

\section{Synthesis of cis,cis-1,3,5-trimethyl-N,N',N'-tris(2-pyridylmethyl)-cis,cis-1,3,5- triaminocyclohexane (Kemp's pyr)}

Triethylamine $(\sim 210 \mu \mathrm{L})$ was added to a suspension of Kemp's triamine $(\mathrm{HCl})_{3}(0.16 \mathrm{~g}, 0.51$ mmole) in $\mathrm{MeOH}(3.0 \mathrm{~mL})$ adjusting the $\mathrm{pH}$ of the solution to 6.0 to 6.5. Sodium cyanoborohydride $(0.10 \mathrm{~g}, 1.63 \mathrm{mmole})$ and 2-pyridinecarboxaldehdye $(0.05 \mathrm{~mL}, 1.53 \mathrm{mmole})$ were then added to the solution and the mixture stirred at room temperature for 3 days. The $\mathrm{pH}$ of the solution was checked regularly and maintained at $\sim 6.5$ by addition of either glacial acetic acid or triethylamine. The solvent was then removed in vacuo and the solid taken up in $\mathrm{CH}_{2} \mathrm{Cl}_{2}(25 \mathrm{~mL})$. The mixture was then washed with cold $\mathrm{H}_{2} \mathrm{O}(3 \times 10 \mathrm{~mL})$ and the organic layer dried over $\mathrm{MgSO}_{4}$ for $30 \mathrm{~min}$. The organic layer was filtered and the solvent was removed in vacuo to give a brown oil. The product was purified on a basic alumina column eluted using a slow gradient of $\mathrm{MeOH}(1-10 \%)$ in $\mathrm{CH}_{2} \mathrm{Cl}_{2}(0.19 \mathrm{~g}, 85 \%$ yield $)$. The $\mathrm{HCl}$ acid form is isolated as by adding a $\mathrm{HCl}_{(\mathrm{g})}$ saturated solution of dioxane to a solution of the Kemp's pyr in dioxane. FAB/MS: $m / z\left[\mathrm{C}_{27} \mathrm{H}_{36} \mathrm{~N}_{6}+\mathrm{H}\right]^{+}$calcd: 445.3 , found: 445.4. ${ }^{1} \mathrm{H}$ NMR of the free base $\left(\mathrm{CDCl}_{3}\right): \delta 1.20\left(\mathrm{~s}, 9 \mathrm{H}, \mathrm{CH}_{3}\right), 1.27\left(\mathrm{~s}, 2 \mathrm{H}, \mathrm{CH}_{2}\right), 1.25\left(\mathrm{~d}, 2 \mathrm{H}, J 13.3 \mathrm{~Hz}, \mathrm{CH}_{2}\right), 2.34(\mathrm{~d}, 2 \mathrm{H}$, $\left.J 13.3 \mathrm{~Hz}, \mathrm{CH}_{2}\right), 3.95\left(\mathrm{~s}, 6 \mathrm{H}, \mathrm{CH}_{2}\right), 6.98(\mathrm{dt}, 3 \mathrm{H}, J 6.0,1.7 \mathrm{~Hz}, \mathrm{Ar}), 7.06(\mathrm{~d}, 3 \mathrm{H}, J 8.6 \mathrm{~Hz}$, $A r), 7.33(\mathrm{dt}, 3 \mathrm{H}, J 8.6,1.7 \mathrm{~Hz}, A r), 8.08(\mathrm{dt}, 3 \mathrm{H}, J 5.1,1.7 \mathrm{~Hz}, A r) ;{ }^{13} \mathrm{C} \mathrm{NMR}\left(\mathrm{CDCl}_{3}\right): 30.5$, 45.7, 48.6, 54.2, 121.3, 122.2, 136.1, 148.8, 160.8. Analysis calculated for $\mathrm{C}_{27} \mathrm{H}_{36} \mathrm{~N}_{6} \bullet 6 \mathrm{HCl} \bullet 4 \mathrm{H}_{2} \mathrm{O}: \mathrm{C}, 44.07 ; \mathrm{H}, 6.86 ; \mathrm{N}, 11.43$. Found: $\left(\mathrm{C}_{27} \mathrm{H}_{36} \mathrm{~N}_{6} \bullet 6 \mathrm{HCl} \bullet 4 \mathrm{H}_{2} \mathrm{O}\right) \mathrm{C}$, 44.31; H, 6.99; N, 11.24.

\section{Synthesis of the $\mathrm{Cu}(\mathrm{II})$ complex of Kemp's pyr}

A solution of Kemp's pyr $(0.10 \mathrm{~g}, 0.23 \mathrm{mmole})$ in $\mathrm{MeOH}(2.0 \mathrm{~mL})$ was added dropwise to a stirred solution of copper(II) tetrafluoroborate $(0.08 \mathrm{~g}, 0.23 \mathrm{mmole})$ in $\mathrm{MeOH}(1.0 \mathrm{~mL})$ under Argon. The mixture was then stirred for 3 hours at $0^{\circ} \mathrm{C}$. The green precipitate that formed was 
then filtered off, washed with cold $\mathrm{MeOH}$, and dried in vacuo ( $0.09 \mathrm{~g}, 60 \%$ yield). Single crystals were grown by diffusing $\mathrm{Et}_{2} \mathrm{O}$ in the $\mathrm{EtOH}$ solution of the $\mathrm{Cu}$ (II) complex. FAB/MS: $m / z\left[\left(\mathrm{C}_{27} \mathrm{H}_{36} \mathrm{~N}_{6}\right) \mathrm{Cu}\left(\mathrm{OH}_{2}\right)(\mathrm{OH})\right]^{+}$calcd: 542.8 , found: $542.8, m / z\left[\mathrm{C}_{27} \mathrm{H}_{36} \mathrm{~N}_{6}+\mathrm{H}\right]^{+}$calcd:

445.3, found: 445.2. Analysis calculated for $\left(\mathrm{B}_{2} \mathrm{C}_{27} \mathrm{CuF}_{8} \mathrm{H}_{36} \mathrm{~N}_{6} \cdot 1.75 \mathrm{H}_{2} \mathrm{O}\right) \mathrm{C}, 45.44 ; \mathrm{H}, 5.58$; $\mathrm{N}$, 11.79. Found: $\left(\mathrm{B}_{2} \mathrm{C}_{27} \mathrm{CuF}_{8} \mathrm{H}_{36} \mathrm{~N}_{6} \bullet 1.75 \mathrm{H}_{2} \mathrm{O}\right) \mathrm{C}, 45.428 ; \mathrm{H}, 5.292 ; \mathrm{N}, 11.688$.

\section{Synthesis of $\mathrm{Zn}$ (II) complex of Kemp's pyr}

The zinc complex of Kemp's pyr was synthesized as described above of the analogous $\mathrm{Cu}$ (II) complex using an equimolar amount zinc(II) chloride. ESI/TOF/MS: $m / z\left[\left(\mathrm{C}_{27} \mathrm{H}_{36} \mathrm{~N}_{6}\right)\right.$ $\mathrm{ZnCl}]^{+}$calcd: 544.3, found: 543.1, $\mathrm{m} / z\left[\left(\mathrm{C}_{27} \mathrm{H}_{36} \mathrm{~N}_{6}\right) \mathrm{Zn}\left(\mathrm{HCO}_{2}{ }^{-}\right)\right]^{+}$calcd: 554.3, found: 553.2. H NMR ( $\left.\mathrm{D}_{2} \mathrm{O}, \mathrm{TSP}\right): \delta 1.35\left(\mathrm{~s}, 9 \mathrm{H}, \mathrm{CH}_{3}\right), 1.68\left(\mathrm{~d}, 2 \mathrm{H}, \mathrm{J} 27.6 \mathrm{~Hz}, \mathrm{CH}_{2}\right), 2.35(\mathrm{~d}, 2 \mathrm{H}, J 15.6$ $\left.\mathrm{Hz}, \mathrm{CH}_{2}\right), 3.85$ (t, $\left.2 \mathrm{H}, J 8.4 \mathrm{~Hz}, \mathrm{CH}_{2}\right), 4.28\left(\mathrm{~d}, 6 \mathrm{H}, J 8.4 \mathrm{~Hz}, \mathrm{CH}_{2}\right), 7.38(\mathrm{t}, 3 \mathrm{H}, J 6 \mathrm{~Hz}, \mathrm{Ar})$, $7.51(\mathrm{~d}, 3 \mathrm{H}, J 6 \mathrm{~Hz}, A r), 7.55$ (d, 3H, $J 8 \mathrm{~Hz}, A r), 8.02(\mathrm{t}, 3 \mathrm{H}, J 8 \mathrm{~Hz}, A r) .{ }^{13} \mathrm{C}$ NMR $\left(\mathrm{D}_{2} \mathrm{O}\right)$ : 29.6, 43.9, 46.0, 56.2, 125.0, 125.2, 141.5, 147.3, 158.0.

\section{Crystallographic Data}

Crystal data and refinement details are reported in Table 1. A single crystal of $\mathrm{Cu}(\mathrm{II})-\mathrm{Kemp}$ 's pyr $(0.40 \times 0.20 \times 0.15 \mathrm{~mm})$, crystallized by diffusion of diethyl ether into a solution in ethanol, was mounted using Paratone ${ }^{\circledR}$ oil onto a glass fiber and cooled to the data collection temperature of $120^{\circ} \mathrm{K}$. Data were collected on a Brüker-AXS APEX CCD diffractometer with $0.71073 \AA$ Mo-Ka radiation. Unit cell parameters were obtained from 60 data frames, $0.3^{\circ}$ $\omega$, from three different sections of the Ewald sphere. No symmetry higher than triclinic was evident from the diffraction data. Solution in the centrosymmetric space group $P-1$ yielded chemically reasonable and computationally stable results of refinement. The data-set was treated with SADABS adsorption corrections based on redundant multiscan data ${ }^{50} T_{\max } /$ $T_{\min }=1.143$. Two symmetry-unique isomers were located in the asymmetric unit yielding $Z$ $=2$, and $Z^{\prime}=2$. Data set was treated with Squeeze filter (Platon) 51 consistent with initial solutions showing three ethanol molecules co-crystallized for every two copper complexes. All non-hydrogen atoms were refined with anisotropic displacement parameters. All hydrogen atoms were treated as idealized contributions. Structure factors are contained 13 in the SHELXTL 6.12 program library 52 . The CIF is available from the Cambridge Crystallographic Data Center.

\section{In vitro cell proliferation assay}

HeLa cells were obtained from the American Type Culture Collection and grown in a humidified $5 \% \mathrm{CO}_{2}$ atmosphere at $37^{\circ} \mathrm{C}$ in DME medium (Gibco BRL) supplemented with $10 \%$ fetal bovine serum and penicillin/streptomycin. Cells $\left(2 \times 10^{3}\right)$ were plated in 96 well tissue culture dishes and allowed to attach overnight before test compounds were added. Six replicate cultures were used for each point. After $72 \mathrm{~h}$, viability was assessed using an MTT assay, in which (3-(4,5-dimethylthiazol-2-yl)-2,5-diphenyl tetrazolium bromide is added to the medium and the formation of a reduced product is assayed by measuring the optical density at $560 / 650 \mathrm{~nm}$ after 3 hours. Color formation is proportional to viable cell number 53 .

\section{Supplementary Material}

Refer to Web version on PubMed Central for supplementary material.

\section{Acknowledgement}

This work was supported in part by grant No.DK 57781 (S.V.T.) from the National Institutes of Health and in part by the Intramural Research Program of the NIH (National Cancer Institute). 


\section{References}

1. Kaim, W.; Schwederski, B. Bioinorganic Chemistry: Inorganic Elements in the Chemistry of Life. An Introduction and Guide. West Sussex: John Wiley \& Sons Ltd.; 1996. Historical Background, Current Relevance and Perspectives; p. 1-5.

2. Helmut Beinert. Development of the Field and Nomenclature. Lovenberg, Walter. [1], 1-36. 1973. In: Horecker; Bernard; Kaplan; Nathan, O.; Marmur; Julius; Scheraga; Harold, A., editors. New York, Academic Press, Inc. Molecular Biology, An International Series of Monographs and Textbooks. 1973.

3. Halliwell, B.; Gutteridge, JMC. Free Radicals in Biology and Medicine. Third ed.. New York: Oxford University Press Inc.; 1999. The chemistry of free radicals and related 'reactive species'; p. 36-104.

4. Deroche A, Morgenstern-Badarau I, Cesario M, Guilhem J, Keita B, Nadjo L, Houée-Levin C. A sevencoordinate manganese(II) complex formed with a single tripodal heptadentate ligand as a new superoxide scavenger. J. Am. Chem. Soc 1996;118:4567-4573.

5. Morgenstern-Badarau I, Lambert F, Renault JP, Cesario M, Maréchal J-D, Maseras F. Amine conformational change and spin conversion induced by metal-assisted ligand oxidation: from the seven-coordinate iron(II)-TPAA complex to the oxidized iron(II)-(py)3 tren isomers. Characterization, crystal structures, and density functional study. Inorg. Chim. Acta 2000;297:338-350.

6. Hoselton MA, Wilson LJ, Drago RS. Substituent effects on the spin equilibrium observed with hexadentate ligands on iron(II). J. Am. Chem. Soc 1975;97:1722-1729.

7. Brittenham GM, Weiss G, Brissot P, Lainê F, Guillygomarc'h A, Guyader D, Moirand R, Deugnier Y. Clinical consequences of new insights in the pathophysiology of disorders of iron and heme metabolism. Am. Soc. Hematol 2000:39-50.

8. Cazzola M, Bergamaschi G, Dezza L, Arosio P. Manipulation of cellular iron metabolism for modulating normal and malignant cell proliferation: Achievements and prospects. Blood 1990;75:1903-1919. [PubMed: 2186818]

9. Richardson DR. Mysteries of the transferrin-transferrin receptor 1 interaction uncovered. Cell 2004;116:486-485.

10. Torti; Suzy, V.; Planalp; Roy, P.; Brechbiel; Martin, W.; Park; Gyungse; Torti; Frank, M. Abraham, Nadar. [6]. New York: Kluwer Academic/Plenum Publishers. Molecular Biology of Hematopoiesis; 1999. Iron chelation in cancer therapy; p. 381-389.

11. Lederman HM, Cohen A, Lee JWW, Freedman MH, Gelfand EW. Desferrioxamine: A reversible Sphase inhibitor of human lymphocyte proliferation. Blood 1984;64:748-753. [PubMed: 6380622]

12. Hoffbrand AV, Ganeshaguru K, Hooton JWL, Tattersall MHN. Effect of iron deficiency and desferrioxamine on DNA synthesis in human cells. Br. J. Hematol 1976;33:517-526.

13. Brown NC, Elliasson R, Reichard P, Thelander L. Spectrum and iron content of protein B2 from ribonucleotide diphosphate reductase. Eur. J. Biochem 1969;9:512. [PubMed: 4896735]

14. Schafer, AI.; Bunn, HF. Iron-deficiency and Iron-loading Anemias. In: Petersdorf, RG.; Adams, RD.; Braunwald, E.; Isselbacher, KJ.; Martin, JB.; Wilson, JD., editors. Harrison's Principles of Internal Medicine. Tenth ed.. New York: McGraw-Hill Book Company; 1983. p. 1848-1853.

15. Gao J, Richardson DR. The potential of iron chelators of the pyridoxal isonicotinoyl hydrazone class as effective antiproliferative agents, IV: The mechanisms involved in inhibiting cell-cycle progression. Blood 2001;98:842-850. [PubMed: 11468187]

16. Joynson DHM, Jacobs A, Murray-Walker D, Dolby AE. Defect of cell-mediated immunity in patients with iron-deficiency anaemia. Lancet 1972;300:1058-1059. [PubMed: 4117379]

17. Robbins E, Pederson T. Iron: Its intracellular localization and possible role in cell division. Proc. Natl. Acad. Sci. USA 1970;66:1244-1251. [PubMed: 4920092]

18. Hill RS, Petitt JE, Tattersall MHN, Kiley N, Lewis SM. Iron deficiency and dyserythropoiesis. Br. J. Haematol 1972;23:507-512. [PubMed: 5084814]

19. Hershko CH, Karsai A, Eylon L, Izak G. The effect of chronic iron deficiency on some biochemical functions of the human hemopoietic tissue. Blood 1970;36:321-329. [PubMed: 5451922]

20. van der Weyden M, Rother M, Firkin B. Megaloblastic maturation masked by iron deficiency: A biochemical basis. Br. J. Haematol 1972;22:299-307. [PubMed: 5013825]

21. Brockman RW, Shaddix S, Stringer V, Adamson D. Enhancement by desferrioxamine of inhibition of DNA synthesis by ribonucleotide reductase inhibitors. P. Am. Assoc. Canc. Res 1972;13:88. 
22. Laster WR Jr, Brockman RW. Enhancement of the activity of 5-hydroxypyridine-2-carboxaldehyde thiosonicarbazone (HCT) by desferrioxamine mesylate (Desferal(R)) in vivo. Proceedings of the American Association of Cancer Research 1973;14:18.

23. Le NTV, Richardson DR. The role of iron in cell cycle progression and the proliferation of neoplastic cells. Biochim. Biophys. Acta 2002;1603:31-46. [PubMed: 12242109]

24. Richardson DR. Analogues of pyridoxal isonicotinoyl hydrazone (PIH) as potential iron chelators for the treatment of neoplasia. Leuk. Lymphoma 1998;31:47-60. [PubMed: 9720714]

25. Rakba N, Loyer P, Gilot D, Delcros JG, Glaise D, Baret P, Piere JL, Brissot P, Lescoat G. Antiproliferative and apoptotic effects of O-Trensox, a new synthetic iron chelator, on differentiated human hepatoma cell lines. Carcinogenesis 2000;21:943-951. [PubMed: 10783316]

26. Aouad F, Florence A, Zhang Y, Collins F, Henry C, Wad RJ, Crichton RR. Evaluation of new iron chelators and their therapeutic potential. Inorg. Chim. Acta 2002;339:470-480.

27. Torti SV, Torti FM, Whitman SP, Brechbiel MW, Park G, Planalp RP. Tumor cell cytotoxicity of a novel metal chelator. Blood 1998;92:1384-1389. [PubMed: 9694727]

28. Hann H-WL, Stahlhut MW, Blumberg BS. Iron nutrition and tumor growth: Decreased tumor growth in iron-deficient mice. Cancer Research 1988;48:4168-4170. [PubMed: 3390810]

29. Blatt J, Stitely S. Antineuroblastoma activity of desferrioxamine in human cell lines. Cancer Research 1987;47:1749-1750. [PubMed: 3815370]

30. Becton DL, Bryles P. Desferioxamine inhibition of human neuroblastoma viability and proliferation. Cancer Research 1988;48:7189-7192. [PubMed: 3191493]

31. Donfrancesco A, Deb G, Dominici C, leggi D, Castello MA, Helson L. Effects of a single course of desferioxamine in neuroblastoma patients. Cancer Research 1990;50:4929-4930. [PubMed: 2379156]

32. Donfrancesco A, Deb G, Dominici C. Desferioxamine, cyclophosphamide, etoposide, carboplatin, and thiotepa (D-CECal): A new cytoreductive chelation-chemotherapy regimen in patients with advanced neuroblastoma. Am. J. Clin. Oncol 1992;15:319-322. [PubMed: 1514528]

33. Donfrancesco A, de Bernardi B, Carli M. Desferioxamine (D) followed by cytoxan (C), etoposide (E), carboplatin (Ca), thio-TEPA (T), induction regimen in advanced neuroblastoma. Eur. J. Cancer 1995;31A:612-615. [PubMed: 7576980]

34. Richardson DR. Analogues of pyridoxal isonicotinoyl hydrazone (PIH) as potential iron chelators for the treatment of neoplasia. Leuk. Lymphoma 1998;31:47-60. [PubMed: 9720714]

35. Abeysinghe RD, Greene BT, Haynes R, Willingham MC, Turner J, Planalp RP, Brechbiel MW, Torti FM, Torti SV. p53-Independent apoptosis mediated by tachpyridine, an anti-cancer iron chelator. Carcinogenesis 2001;22:1607-1614. [PubMed: 11576999]

36. Park G, Lu FH, Ye N, Brechbiel MW, Torti SV, Torti FM, Planalp RP. Novel iron complexes and chelators based on cis,cis-1,3,5-triaminocyclohexane: iron-mediated ligand oxidation and biochemical properties. J. Biol. Inorg. Chem 1998;3:449-457.

37. Park G, Ye N, Rogers RD, Brechbiel MW, Planalp RP. Effect of metal size on coordination geometry of $N, N^{\prime}, N^{\prime \prime}$-tris(2-pyridylmethyl)- cis,cis-1,3,5-triaminocyclohexane: synthesis and structure of $\left[\mathrm{M}^{\mathrm{IIL}}\right]\left(\mathrm{ClO}_{4}\right)_{2}(\mathrm{M}=\mathrm{Zn}, \mathrm{Cd}$ and $\mathrm{Hg})$. Polyhedron 2000;19:1155-1161.

38. Hancock RD, Martell AE. Ligand design for selective complexation of metal ions in aqueous solution. Chem. Rev 1989;89:1875-1914.

39. Busch DH. The compleat coordination chemistry - one practioner's perspective. Chem. Rev 1993;93:847-860.

40. Hou Z, Stack TDP, Sunderland CJ, Raymond KN. Enhanced iron(III) chelation through ligand predisposition: syntheses, structures and stability of tris-catecholate enterobactin analogs. Inorg. Chim. Acta 1997;263:341-355.

41. Menger FM, Bian J, Azov VA. A 1,3,5-triaxial triaminocyclohexane: The triamine corresponding to Kemp's triacid. Angew. Chem. Int. Ed 2002;41:2581-2584.

42. Bowen T, Planalp RP, Brechbiel MW. An improved synthesis of cis, cis-1,3,5-triaminocyclohexane. Synthesis of novel hexadentate ligand derivatives for the preparation of gallium radiopharmaceuticals. Bioorg. Med. Chem. Lett 1996;6:807-810.

43. Menger FM, Ladika M. Fast hydrolysis of an aliphatic amide at neutral $\mathrm{pH}$ and ambient temperature: A peptidase model. J. Am. Chem. Soc 1988;110:6794-6796. 
44. Borch R, Durst HD. Lithium cyanohydridoborate, a versatile new reagent. J. Am. Chem. Soc 1969;91:3996-3997.

45. Borch RF, Bernstein MD, Durst HD. The cyanohydridoborate anion as a selective reducing agent. J. Am. Chem. Soc 1971;93:2897-2904.

46. Fleischer EB, Gebala AE, Swift DR, Tasker PA. Trigonal prismatic-coctahedral coordination. Complexes of intermediate geometry. Inorg. Chem 1972;11:2775-2784.

47. Park G, Dadachova E, Przyborowska A, Lai S, Ma D, Broker G, Rogers RD, Planalp RP, Brechbiel MW. Synthesis of novel 1,3,5-cis,cis-triaminocyclohexane ligand based $\mathrm{Cu}$ (II) complexes as potential radiopharmaceuticals and correlation of structure and serum stability. Polyhedron 2001;20:3155-3163.

48. Bondi A. van der Waals volumes and radii. J. Phys. Chem 1964;68:441-451.

49. Hilfiker KA, Brechbiel MW, Rogers RD, Planalp RP. Tricationic metal complexes ([ML] $\left[\mathrm{NO}_{3}\right]_{3}, \mathrm{M}$ $=\mathrm{Ga}, \mathrm{In}$ ) of $N, N^{\prime}, N^{\prime \prime}$-tris(2-pyridylmethyl)-cis-1,3,5-triaminocyclohexane: Preparation and structure. Inorg. Chem 1997;36:4600-4603. [PubMed: 11670128]

50. Sheldrick, GM. SADABS adsorption corrections program. Bruker-AXS; 2001.

51. Vandersluis P, Spek AL. Bypass - An effective method for the refinement of crystal structures containing disordered solvent regions. Acta Crystallogr., A 1990;46:194-201.

52. Sheldrick, GM. SHELXTL version 6.12 program library. Bruker-AXS; 2001.

53. Mossman T. Rapid colorimetric assay for cellular growth and survival: Application to proliferation and cytotoxicity assays. J. Immunol. Methods 1983;65:55-63. [PubMed: 6606682] 
OPEN<smiles>c1ccc(CNCCN(CCNCc2ccccn2)CCNCc2ccccn2)nc1</smiles>

CLOSE<smiles>c1ccc(CNCCN(CCNCc2ccccn2)CCNCc2ccccn2)nc1</smiles>

\section{trenpyr}
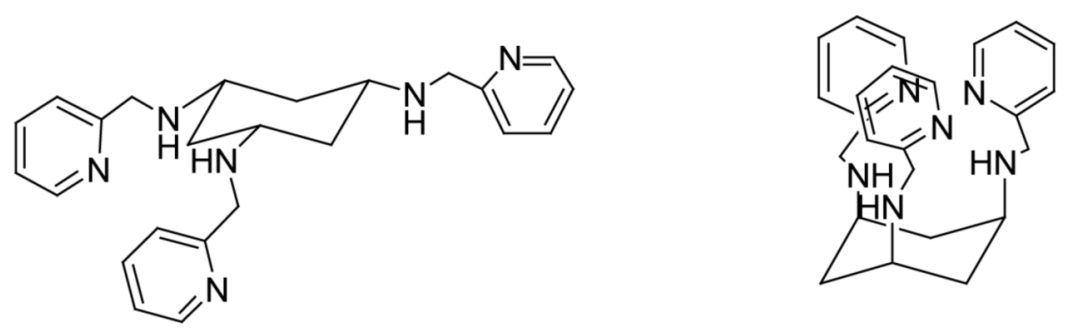

\section{tachpyr}
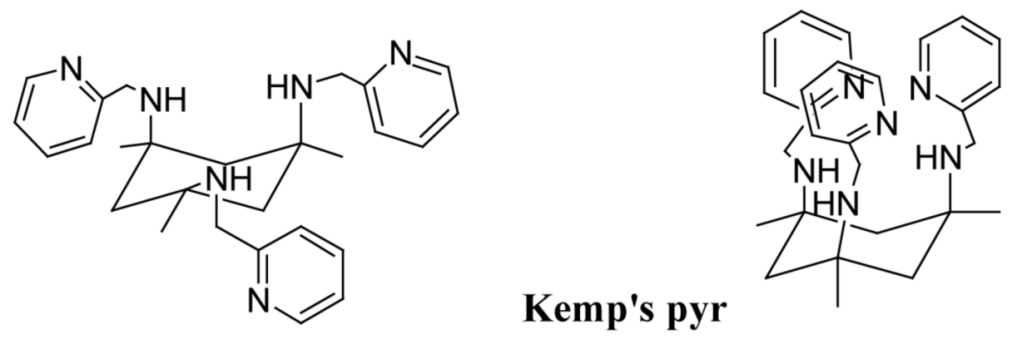

Figure 1.

Conformational changes in structures of the tripodal ligands trenpyr, tachpyr, and Kemp's pyr. 


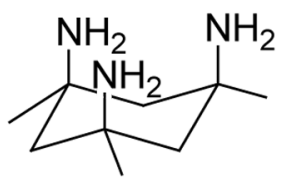<smiles>O=Cc1ccccn1</smiles><smiles>C[12CH3]</smiles>

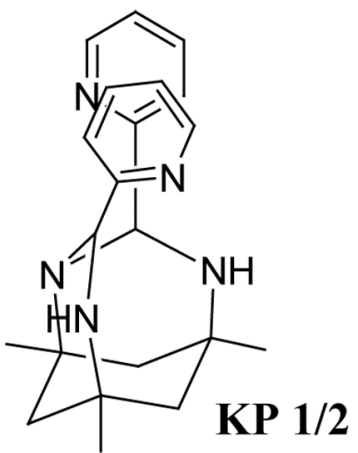

Figure 2.

Synthesis of the tricyclic amine KP1/2; a) benzene, reflux, $12 \mathrm{hr}$. 
<smiles>CC1(N)CC2(C)CN(N)C(C)(C1)C2</smiles>

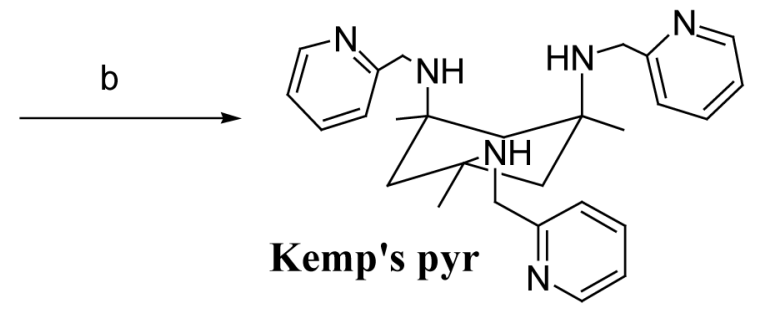

Figure 3.

Synthesis of Kemp's pyr via reductive amination; b) $\mathrm{NaCNBH}_{3}$ in methanol at $\mathrm{pH}$ 6.5, 3 days at room temperature. 


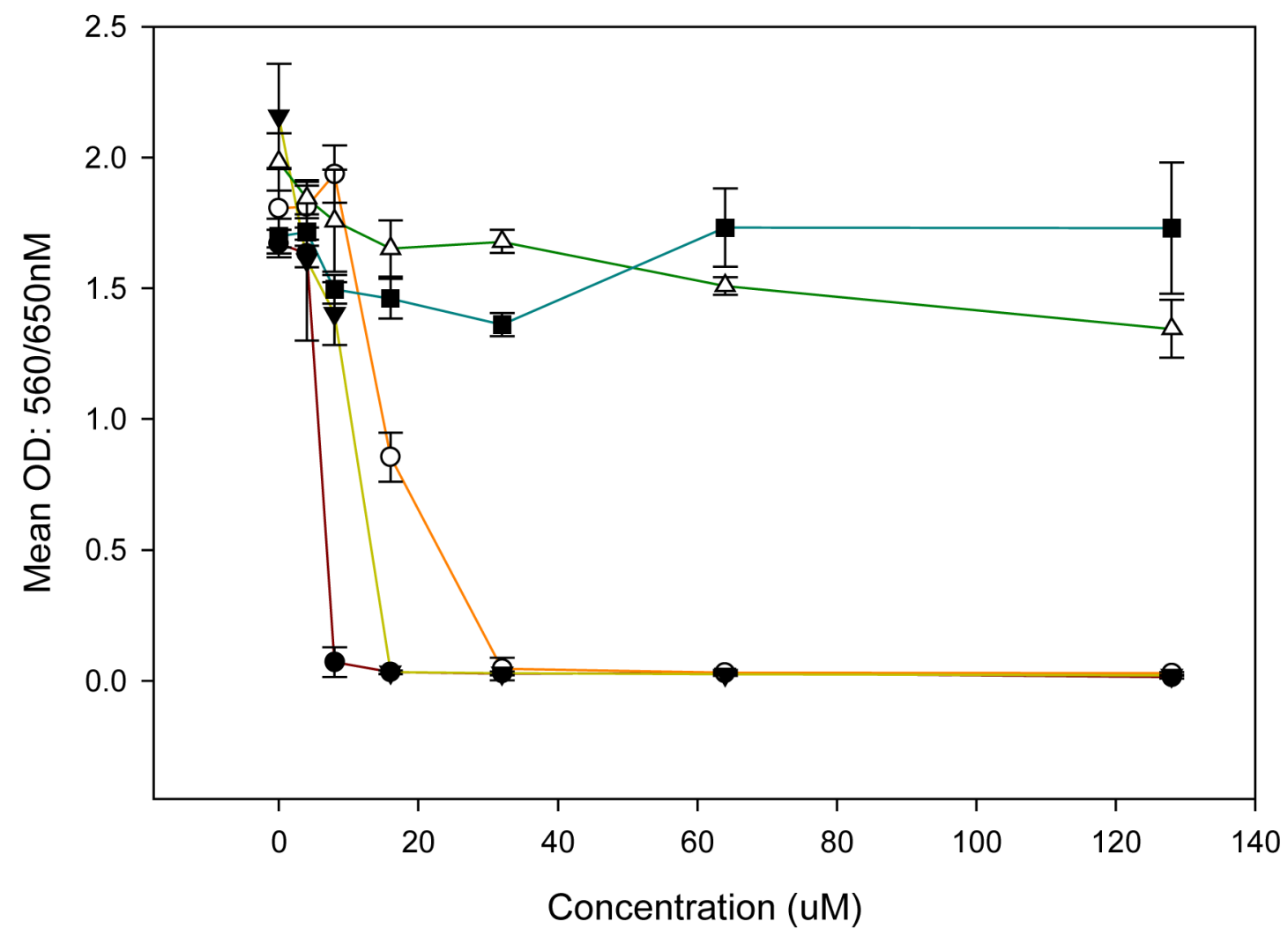

Figure 4.

MTT assay for the HeLa cell treatment with the different triamines after 72 hours. $(\bullet)$ tachpyr, $(\circ)$ trenpyr, ( $\boldsymbol{\nabla})$ Kemp's pyr, ( $\mathbf{\square}) \mathrm{KP} 1 / 2$, and $(\diamond)$ Kemps' triamine. 

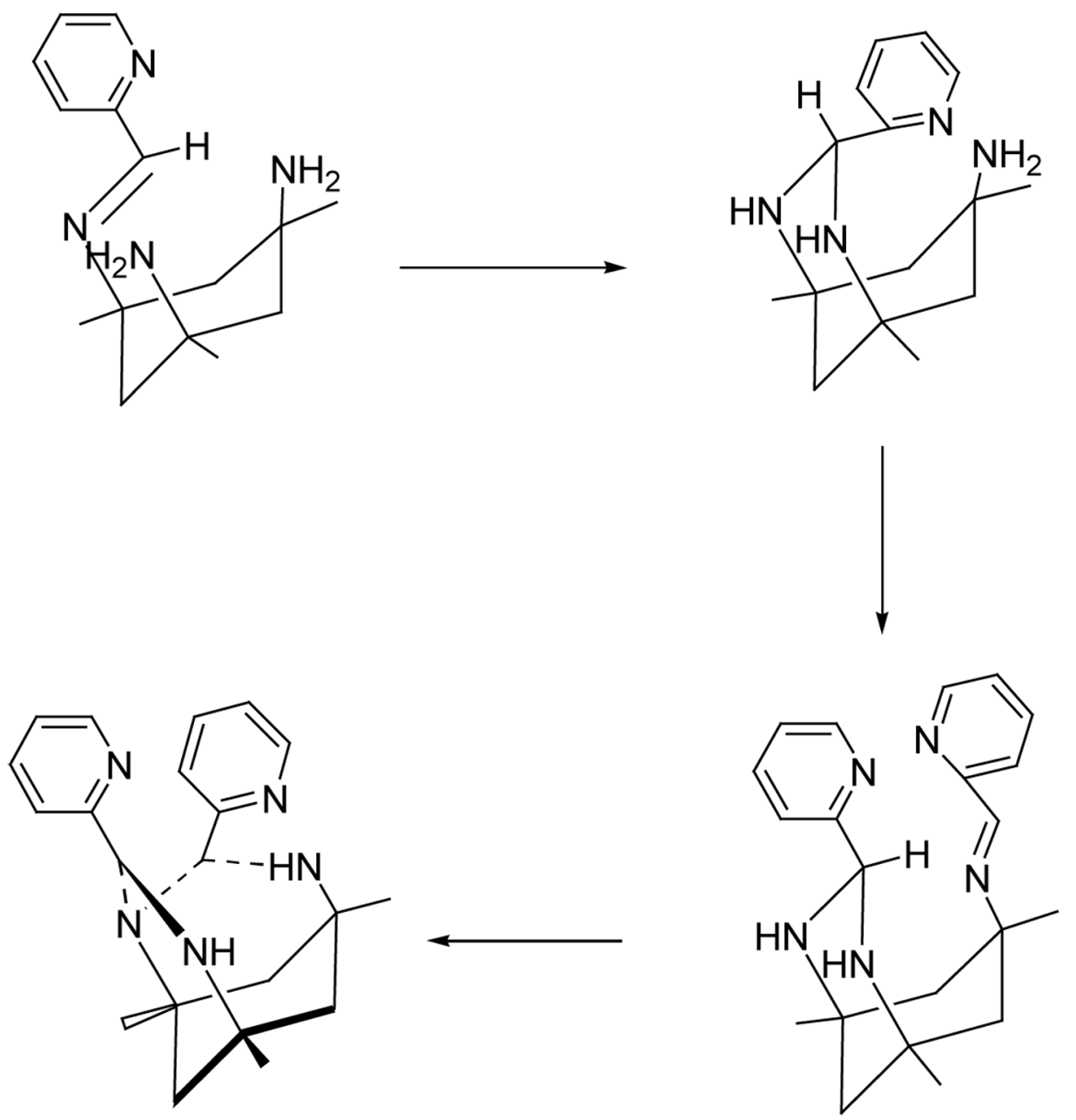

Figure 5.

Scheme for the proposed mechanism for the formation of the tricyclic product KP $1 / 2$. 


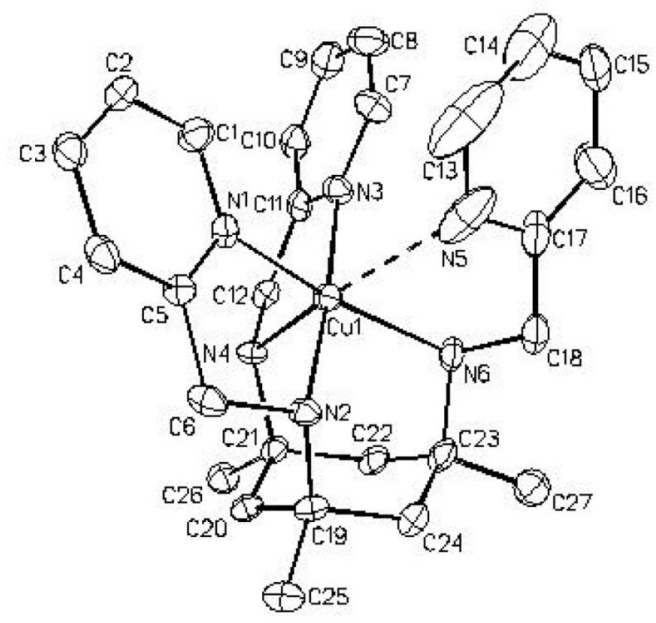

a

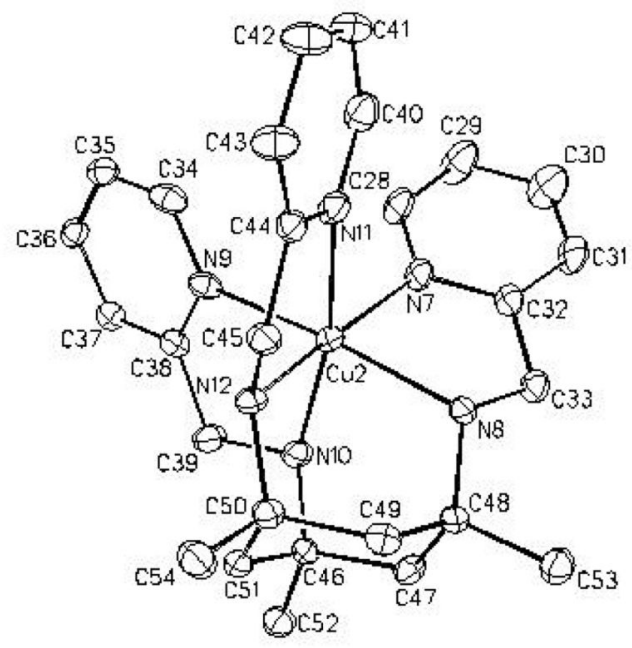

b

Figure 6.

ORTEP drawing of the two isomers of the copper(II) complex of Kemp's pyr (a and b) showing $30 \%$ probability thermal ellipsoids, and the atom-labeling scheme. 


\section{Table 1}

Crystallographic data and refinement details for copper(II) complexes of Kemp's pyr (a and b).

\begin{tabular}{|l|l|}
\hline & $\mathbf{C u}(\mathbf{I I}) \mathbf{K e m p}$ ' pvr \\
\hline Formula & $\mathrm{C}_{30} \mathrm{H}_{45} \mathrm{~B}_{2} \mathrm{CuF}_{8} \mathrm{~N}_{6} \mathrm{O}_{1.50}$ \\
\hline Molecular Weight & 750.88 \\
\hline Crystal system, space group & Triclinic, $P-1$ \\
\hline$a(\AA)$ & $13.0824(17)$ \\
\hline$b(\AA)$ & $14.0531(19)$ \\
\hline$c(\AA)$ & $19.298(3)$ \\
\hline$\alpha\left(^{\circ}\right)$ & $71.371(2)$ \\
\hline$\beta\left({ }^{\circ}\right)$ & $76.996(2)$ \\
\hline$\gamma\left({ }^{\circ}\right)$ & $87.301(2)$ \\
\hline$V\left(\AA^{3}\right)$ & $3274.6(8)$ \\
\hline$Z, Z^{\prime}$ & 2.2 \\
\hline$D_{\text {calc }}\left(\mathrm{mg} / \mathrm{m}^{3}\right)$ & 1.523 \\
\hline Absorption coefficient $\left(\mathrm{mm}^{-1}\right)$ & 0.751 \\
\hline Parameters & 799 \\
\hline Goodness-of-fit on $F^{2}$ & 1.025 \\
\hline Final $R$ indices $[I>2 \sigma(I)]$ & $\mathrm{R} 1=0.0694, \mathrm{wR} 2=0.1475$ \\
\hline$R$ indices (all data $)$ & $\mathrm{R} 1=0.1117, \mathrm{wR} 2=0.1623$ \\
\hline
\end{tabular}

Quantity minimized $=R\left(w F^{2}\right)=\left\{\Sigma\left[w\left(F_{\mathrm{O}}^{2}-F_{\mathrm{c}}{ }^{2}\right)^{2}\right] / \Sigma\left(w F_{\mathrm{O}}{ }^{2}\right)^{2}{ }^{1 / 2}: R(F)=\Sigma \Delta / \Sigma\left(F_{O}\right), \Delta=\left|\left(F_{O}-F_{C}\right)\right|: w=\left[\sigma^{2}\left(\mathrm{~F}_{\mathrm{O}}^{2}\right)+(a P)^{2}+b P\right]^{-1}: P=\left[2 F_{C}{ }^{2}+\right.\right.$ $\operatorname{Max}\left(F_{O}, 0\right] / 3$ 
Table 2

Selected distances $(\AA)$ and angles $\left(^{\circ}\right)$ for the isomers of the copper(II) complexes of the Kemp's pyr (a and b).

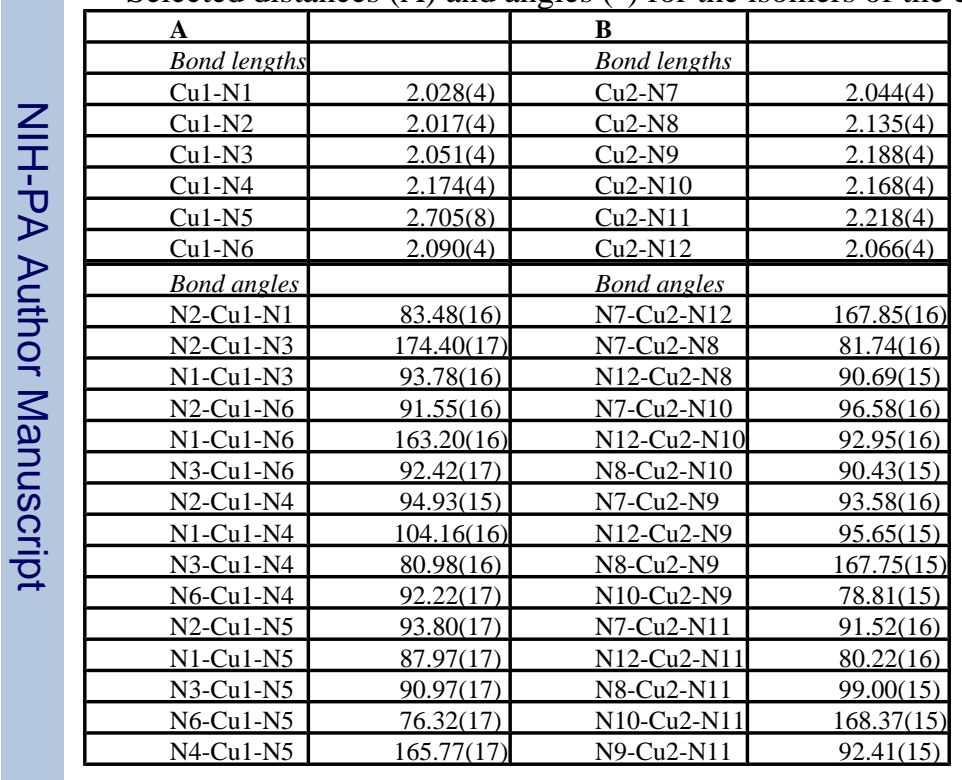

